\title{
Arterial remodelling in palmar fascia and peculiarities of hand microhemodynamics in patients with dupuytren's
} contracture

\author{
-Arterial remodelling in dupuytren's contracture \\ Shchudlo $\mathrm{N}^{1 *}$, Varsegova $\mathrm{T}^{2}$, Stupina $\mathrm{T}^{2}$, Dolganova $\mathrm{T}^{1}$, Shchudlo $\mathrm{M}^{1}$, Shihaleva $\mathrm{N}^{1}$ and Kostin $\mathrm{V}^{1}$ \\ ${ }^{1}$ Clinics and experimental laboratory for reconstructive microsurgery and hand surgery, Russia \\ ${ }^{2}$ Laboratory of morphology of FSBI (Federal State Budget Institution) Russian Ilizarov Scientific Center "Restorative Traumatology and Orthopaedics", Kurgan, Russia
}

\begin{abstract}
Objective: To evaluate the structural changes of arteries in palmar fascia and peculiarities of microhemodynamics in hand arteries of Dupuytren's contracture (DC) patients.

Materials and methods: A cross-sectional study that included patients with DC. The samples of pathologically changed palmar fascia which was excised operatively during partial fasciectomy (DC, $n=49$ ). Control group - histologic samples of normal palmar fascia from patients with open wounds ( $\mathrm{n}=3)$. Depending on the number of layers of smooth muscle cells in media in transverse histologic sections, arteries divided into large (L), medium (M) and small (S) calibers and were measured using computed planimetry. 15 healthy volunteers (men aged between 40 and 67 years) and 10 patients with DC (men aged between 45 and 70 years) before the operation were recruited randomly to carry out the study of hemodynamics in superficial palmar arc and proper palmar digital arteries by pulsed ultrasound Doppler velocimetry (PUDVM).

Results: In S-arteries the luminal diameter was decreased predominantly due to intimal thickening. In M-arteries besides intimal thickening, the outer diameter and muscular layer thickness increased. In L-arteries the outer and lumen diameters decreased, but intimal thickness also increased due to neo-intima formation. Retrograde blood flow, negative values of diastolic velocity, decrease of all calculated PUDVM values were observed in all DC patients. The most expressed decrease of values and indices was noted in zones affected with disease (proper palmar digital arteries for ring and small fingers and superficial palmar arc).
\end{abstract}

Conclusion: Hemodynamic signs of vasoconstriction at the level of superficial palmar were in accordance with structural constrictive remodeling of perforating palmar fascia arteries, the severity of the last depended on the stage of Dupuytren's contracture and arterial caliber.

\section{Introduction}

Dupuytren's disease relates to benign fibro-proliferative disorders which affects predominantly palmar fascia. At the onset one or some angiocentric proliferative nodules grow and then develop cords approximately in $50 \%$ patients [1]. By degrees such cords restrict extension of the fingers (typically ring and small). The majority of patients ignores the beginning of the disease and goes to a doctor having severe metacarpophalangeal or proximal interphalangeal joint contracture. In spite of multiple multidisciplinary researches, aetiology and pathogenesis of Dupuytren's disease is not fully understood.

It was postulated [2] that genetic factors play a major role in the development of Dupuytren's disease but other risk factors - alcohol, smoking, diabetes, manual labor [3] - were also widely reported. It was hypothesized that combination of intrinsic factors (genetic, metabolic, aging) and environmental exposures primarily affects microvascular endothelium, its disfunction induces attraction and accumulation of immune cells, producing cytokines, which mediate fibromatosis leading to Dupuytren's contracture [4].
Only few studies have assessed hand hemodynamics or histology of palmar fascia vasculature in patients with Dupuytren's disease. In plethysmografic study of fingertips blood flow a high incidence of latent vasospastic changes was found [5]. Doppler sonography provides more reliable diagnostic criteria of vasospastic predisposition [6] but publications about using it for patients with Dupuytren's contracture are absent. Narrowing of the capillary lumens with lamination of basal membrane, hyalinosis of arterioles in palmar fascia were revealed

Correspondence to: Shchudlo N, DM, head of clinical and experimental laboratory for reconstructive and restorative microsurgery and hand surgery, Russian Ilizarov Scientific Center for Restorative Traumatology and Orthopaedics of the RF ministry of health, M. Ulianova street 6, 640014, Kurgan, Russia, Tel: 89225631752; E-mail: nshchudlo@mail.ru

Key words: arterial remodeling, Dupuytren's contracture, ultrasound Doppler velocimetry

Received: January 29, 2018; Accepted: February 21, 2018; Published: February 24,2018 
histologically [7] but information about arterial remodeling during Dupuytren's contracture is also absent.

The aim of the present study is to investigate histomorphometric changes of arteries in palmar fascia and peculiarities of microhemodynamics in hand arteries of Dupuytren's contracture patients.

\section{Materials and methods}

\section{Patient's characteristics}

195 patients with Dupuytren's contracture (DC) aged between 27 and 84 years old were operated in FSBI Russian Ilizarov Scientific Center in 2015 through 2017. Majority of patients had the second or third stage of DC according R. Tubiana [8] classification and two of them had the fourth stage. The exclusion criterion was posttraumatic non-Dupuytren's contracture [9] when palmar fascial fibromatosis has not been confirmed clinically and histologically. The inclusion criterion was the evidence of perforating arteries in the samples of pathologically changed palmar fascia which was excised operatively during partial fasciectomy (DC, n=49). DC group was compared with control group - histologic samples of normal palmar fascia from patients with open wounds $(n=3)$.

For characteristic of the DC group the following data were collected: age, sex, durability of the disease and evidence of bilateral affection, number of fingers with impaired function and comorbid conditions.

\section{Histology}

Tissue samples were fixed in mixture of $20 \mathrm{~g} / \mathrm{L}$ solutions of glutaraldehyde and paraformaldehyde in phosphate buffer $(\mathrm{pH}$ 7,4 ) adding $1 \mathrm{~g} / \mathrm{L}$ picric acid and then were embedded in paraffin according to standard protocol. Paraffin sections with a thickness 5-7 $\mu \mathrm{m}$ were prepared on «Reichert» microtome (Austria) and stained with hematoxylin-eosin, Masson's trichrome and Weigert - van Gieson's methods. The true-color images of histologic slides fragments were digitized using the photomicroscope "Opton" (Germany) connected with the "DiaMorph" program complex (Russia, Moscow). Histomorphometry was performed with the "VT-Master-Morphology" program (VideoTest, Russia, St. Petersburg). In reference sets of images from each sample (magnification 200x) shares of vessels (\%) in the sections areas were assessed by a point-counting method using the electronic version of test grid. In images of arteries their external diameters, lumen diameters, wall thickness, intima thickness, media thickness were measured and intima/media ratio was counted.

\section{Pulsed ultrasound Doppler velocimetry}

15 healthy volunteers (men aged between 40 and 67 years) and 10 patients with DC (men aged between 45 and 70 years) before the operation were recruited randomly to carry out the study of hemodynamics in superficial palmar arc and proper palmar digital arteries (according to [10] their average diameters are 1, $7 \pm 0,1 \mathrm{~mm}$ and 1,6 $\pm 0,2 \mathrm{Mm}$ respectively).

Pulsed ultrasound Doppler velocimetry (PUDVM) was performed on diagnostic computer-controlled vessel-scanning instrument "Minimax-Doppler" (Russia) using sensor with operating frequency $20 \mathrm{MHz}$ and operating area $3,14 \mathrm{~mm}^{2}$. Sensor provide transcutaneous measurement of low-velocity blood flow in microvessels with diameter 1, 0-2,0 $\mathrm{mm}$ and depth of location 5-10 $\mathrm{mm}$ [11].

Minimax-Doppler device allows receiving a color spectrum of distribution of a blood flow and its envelopes. The indicators of postcomputer signal processing at standard automatic conclusion were estimated: systolic blood flow velocity $(\mathrm{Vs}, \mathrm{cm} / \mathrm{sec}$ ); mean linear velocity of blood flow $(\mathrm{Vm}, \mathrm{cm} / \mathrm{sec})$, the maximum diastolic velocity along the average velocity curve $(\mathrm{Vad}, \mathrm{cm} / \mathrm{sec})$, volume systolic and mean velocities along the average speed curve (Qas and Qam, ml/ sec). Purselo's resistance index, reflecting the resistance to blood flow distal to the measurement site was calculated by the formula $\mathrm{RI}=(\mathrm{Vs}$ Vad)/Vs. Gosling's pulsatility index, which reflects the resilient-elastic properties of arteries was calculated as $\mathrm{PI}=(\mathrm{Vs}-\mathrm{Vad}) / \mathrm{Vm}$.

\section{Statistical analysis}

For all samples of quantitative data, descriptive statistics parameters were obtained. Taking into account the volume of samples ( $\mathrm{n}$ from 3 to 200), Shapiro-Wilk normality test was performed. For some samples hypothesis of normality was rejected. The majority of numerical data in tables are presented in the form of medians and quartiles (Me (Q1; Q3)). The hypothesis of differences was checked by nonparametric Wilcoxon, Mann-Whitney criteria and Fisher -Irwin exact test with a significance level of 0,05 . For all statistical treatments software package Attestat Program (version 9.3.1, developed by I. P. Gaidyshev, Certificate of Rospatent official registration No. 2002611109) was used.

\section{Results}

\section{Patient's characteristics}

Characteristics of DC group patients are presented in table 1. The main parameters (mean age, male: female ratio, frequency of bilateral affection, durability of the disease, grade of contracture, frequency of cardiovascular disease) in DC group $(\mathrm{n}=49)$ did not differ significantly from those in general group $(\mathrm{n}=195)$.

\section{Histological findings}

With a visual evaluation of micro-preparations, palmar fascia arteries were conditionally divided into three calibers: having less than four layers of smooth muscle cells in media - small caliber, from four to seven layers - medium caliber and more than seven layers - large caliber. Ranges of their outer diameters did not overlap in none of the groups.

Differences in structural changes of arteries in patients with DC depended on the stage of contracture. In the second stage alterations of

Table 1. Characteristics of patient with Dupuytren's contracture $(n=49)$

\begin{tabular}{|l|l|}
\hline Parameter & \multicolumn{2}{l|}{ Value } \\
\hline Demographic characteristics & $(58 \pm 11)(24-77)$ \\
\hline Age $(\mathrm{M} \pm \sigma)($ Min-max) & $11,5: 1$ \\
\hline Male: female ratio & $16(32,7)$ \\
\hline Local state & $(0,5-20)-5(4 ; 10)$ \\
\hline Frequency of bilateral affection n (\%) & $(2-4)-2,5(2 ; 3)$ \\
\hline Disease durability (years) - (Min-max) - Me (Q1; Q3) & $(1-8)-2(1-2)$ \\
\hline Grade of contracture - (Min-max) - Me (Q1; Q3) & \\
\hline Numbers of digits with impaired function (Min-max) - Me (Q1; Q3) & $23(46,9 \%)$ \\
\hline Comorbid conditions n (\%) & $3(6,1 \%)$ \\
\hline Arterial hypertension & $3(6,1 \%)$ \\
\hline Ischemic heart disease & $1(2,2 \%)$ \\
\hline Cardial insuffuciency & $1(2,2 \%)$ \\
\hline Postinfarction cardiosclerosis & $3(6,1 \%)$ \\
\hline Diabetes type 2 & $3(6,1 \%)$ \\
\hline Chronic obstructive pulmonary disease & $2(4,3 \%)$ \\
\hline Chronic hepatitis B & $2(4,3 \%)$ \\
\hline Neuritis of the auditory nerve & \\
\hline Urolithiasis disease & \\
\hline
\end{tabular}


large caliber arteries were minor - single mononuclear inflammatory cells resembling macrophages appeared in sub-intimal layer (Figure 1a). Arteries of medium caliber characterized by hyperplasia of muscular layer and protrusion of modified smooth muscle cells (neointimal cells) in the luminal lining (Figure 1b). Some of small caliber arteries were surrounded by peri-adventitial clusters of mononuclear inflammatory cells resembling predominantly lymphocytes and macrophages (Figure 1c), the others characterized by a significant narrowing of the lumen due to sub-intimal accumulations of foamy cells - vacuolated macrophages (Figure 1d).

In the third stage many of large caliber arteries were with signs of neo-intimal hyperplasia. Thickness of neo-intima varied in different levels of the same arteries (Figures $2 \mathrm{a}$ and $2 \mathrm{~b}$, Figures $2 \mathrm{c}$ and $2 \mathrm{~d}$ ). Special stains allowed revealing the fractures of elastic membranes (Figure 2c) and increase amount of collagen (Figure 2d) in media and neo-intima. In a whole the narrowing of medium and small caliber arteries lumens in patients with third stage was more evident than in second stage. In some cases it was due to depopulation of muscular layer and shrinkage of its fibrous framework (Figure 2e), in other cases - due to the displacement of a large number of cells in the sub-intimal space and bulging of neo-intimal cells into the lumen (Figure 2f).

In patients with fourth stage of disease neo-intimal thickness in some large caliber arteries was striking (Figure 3a), some arteries were with prominent fibrosis of adventitia, fibrosis and hyalinosis of medial and neo-intimal layers (Figure $3 b$ ). The extent of luminal narrowing in all calibers of arteries was varied (Figure $3 \mathrm{c}$,d). Some fully obliterated arteries of small and medium calibers were noted in all patients.

DC group was not uniform in parameter "the share of vessels in area of histological section". In the subgroup of patients younger than 55 years $(\mathrm{n}=18)$ the values $(\mathrm{Me}(\mathrm{Q} 1$; Q3)) were $8,49(6,71 ; 9,39)$ but in the older group $(n=31)$ they were only $5,01(4,18 ; 6,12)-p=0,00037$. Per cent of arteries with signs of mononuclear infiltration and periadventitial clusters of inflammatory cells was $25,67 \%$ in younger subgroup and $11,0 \%$ in older subgroup $(\mathrm{p}<0,05)$.
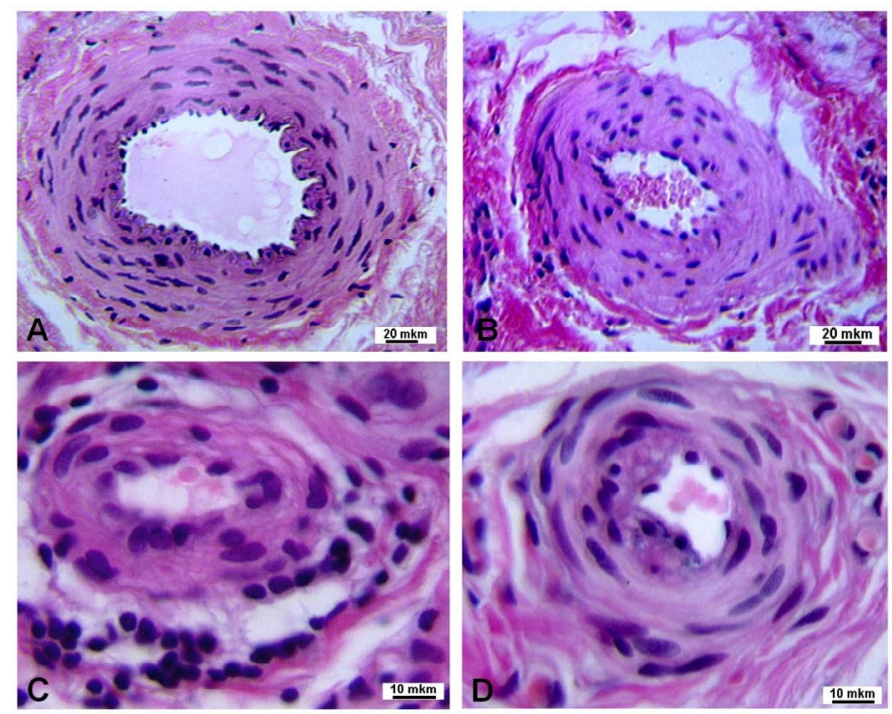

Figure 1. Transverse paraffin sections of palmar fascia arteries from patients with the second stage of Dupuytren's contracture: a - almost normal structure of large caliber artery, $\mathbf{b}$ - medium caliber artery with hyperplastic muscular layer, $\mathbf{c}$ - small caliber arteries with clusters of inflammatory cells in adventitial layer and perivascular tissue $\mathbf{s}, \mathbf{d}$ - smal caliber artery with narrowed lumen. Hematoxylin and eosin stain. Magnification: $\mathbf{a}, \mathbf{b}-200$ $\mathrm{x}, \mathbf{c}, \mathbf{d}-500 \mathrm{x}$.
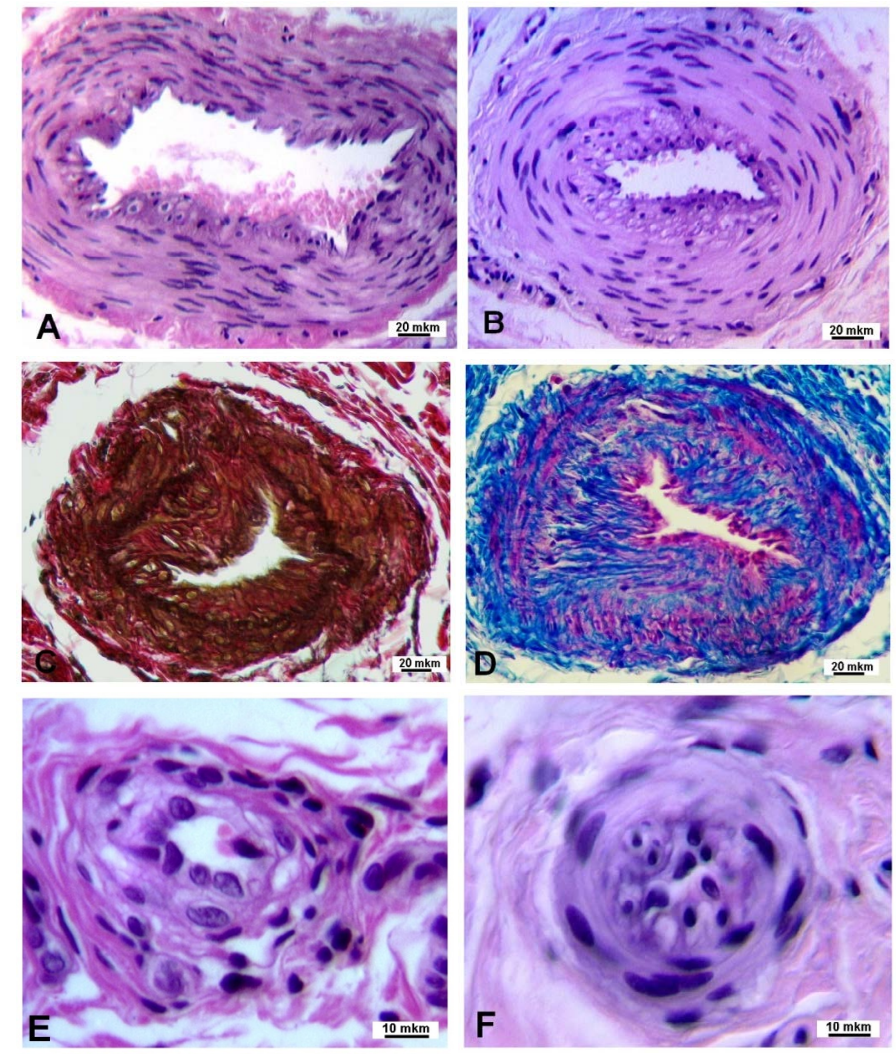

Figure 2. Transverse paraffin sections of palmar fascia arteries in patients with third stage of Dupuytren's contracture. A -D - various extent of neointimal thickening in large caliber arteries, $\mathbf{C}$ - breakdown of inner elastic laminae (dark brown color), $\mathbf{D}$ - increased amounts of collagen (blue color). $\mathbf{E}$ - shrinkage of wall in small artery. $\mathbf{F}$ - almost fully closed lumen in small artery. Staining: A, B, E, F - hematoxylin-eosin; C - Weigert - van Gieson; D - Masson's trichrome. Magnification: A-D - 200x, E, F - 500x.

Diameters of arteries of small (S) caliber (Table 2) did not differ from control, in medium (M) caliber it was significantly increased (Table 3) compared to the control at $16 \%(\mathrm{p}=0,0004)$, but in large (L) caliber decreased (Table 4$)$ at $19 \%(p=0,0022)$. Luminal diameter of $S$ arteries (Table 2) was decreased compared to the control at $29 \%$ ( $\mathrm{p}=0$, $0026)$, in $\mathrm{M}$-arteries (Table 3$)$ - at $19 \%(\mathrm{p}=0,0083)$ and in L-arteries (Table 4) also decreased at 39\% ( $\mathrm{p}=3,49 \mathrm{E}-06)$.

Wall thickness in $\mathrm{S}$ - and $\mathrm{M}$-arteries (Tables 2,3) compared to the control was increased at $27 \%(\mathrm{p}=0,0020)$ and $60 \%(\mathrm{p}=1,01 \mathrm{E}-09)$ respectively but in L-arteries (Table 4 ) did not differ from the control. Thickness of intima in all calibers was increased compared to the control (Tables 2-4). Thickness of media was significantly increased only in $\mathrm{M}$-arteries (Table 3$)$ - $(\mathrm{p}=3,88 \mathrm{E}-06)$, in S- and L-caliber (Tables 2 and 4 ) it did not differ from the control. Thickness of intima/media ratio was increased compared to the control in all calibers (Tables 2-4) of arteries: in $S-1,4$ times $(p=0,0024)$, in $M-3,3$ times $(p=4,52 E-10)$, in $\mathrm{L}-2,9$ times ( $\mathrm{p}=0,0008)$.

\section{Microhemodinamics in hand arteries}

In healthy subjects the prominent systolic and the second anterograde peaks were recorded. The retrograde flow was absent and the values of $\mathrm{Vad}$ was positive (Figure 4). Normal $\mathrm{Vm} / \mathrm{Vs}$ ratio was more than $50 \%-61,0 \%$ in average (Table 5).

In DC patients according to hand PUDVM data (Figure 5) VAd $<1$, $\mathrm{Vm} / \mathrm{Vs}<50 \%, \mathrm{PI}>1,4$ were recorded. The most expressed decrease of values and indices was noted in zones affected with disease (proper 

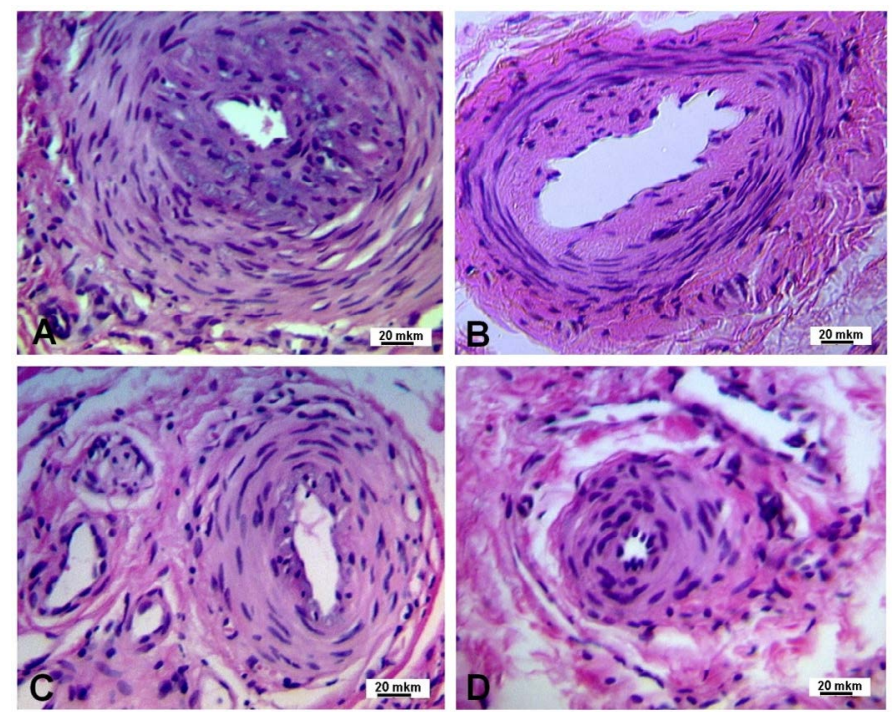

Figure 3. Transverse paraffin sections of palmar fascia arteries from patients with the fourth stage of Dupuytren's contracture. A - severe narrowing of large caliber artery lumen due to neo-intimal thickening. B - fibrosis and hyalinosis of large caliber artery. $\mathbf{C}, \mathbf{D}$ - various extent of lumen narrowing and muscular layer thickening in medium and small caliber arteries. Hematoxylin-eosin staining. Magnification $-200 x$.

Table 2. Morphometric characteristics of arteries of small (S) caliber in control subjects and Dupuytren's contracture group (Me (Q1; Q3))

\begin{tabular}{|l|l|l|l|}
\hline $\begin{array}{l}\text { Group/ } \\
\text { parameters }\end{array}$ & Control & $\begin{array}{l}\text { Dupuytren's } \\
\text { contracture group }\end{array}$ & p \\
\hline Diameter of artery $(\mu \mathrm{m})$ & $71,83(47,60 \div 97,68)$ & $72,85(57,39 \div 98,84)$ & $>0,05$ \\
\hline Lumen diameter $(\mu \mathrm{m})$ & $33,84(25,81 \div 45,27)$ & $24,15(16,37 \div 36,04)$ & 0,0026 \\
\hline Wall thickness $(\mu \mathrm{m})$ & $20,54(10,90 \div 27,38)$ & $26,13(20,03 \div 32,43)$ & 0,0020 \\
\hline Thickness of intima $(\mu \mathrm{m})$ & $2,02(1,07 \div 2,81)$ & $3,21(2,08 \div 5,47)$ & $3,56 \mathrm{E}-05$ \\
\hline Thickness of media $(\mu \mathrm{m})$ & $13,51(5,65 \div 19,48)$ & $15,94(11,83 \div 20,15)$ & $>0,05$ \\
\hline $\begin{array}{l}\text { Intima/ media thickness } \\
\text { ratio }\end{array}$ & $0,16(0,15 \div 0,18)$ & $0,22(0,15 \div 0,33)$ & $\mathrm{p}=0,0024$ \\
\hline
\end{tabular}

Table 3. Morphometric characteristics of arteries of medium (M) caliber in control subjects and Dupuytren's contracture group (Me (Q1; Q3))

\begin{tabular}{|l|l|l|l|}
\hline $\begin{array}{l}\text { Group/ } \\
\text { parameters }\end{array}$ & Control & $\begin{array}{l}\text { Dupuytren's } \\
\text { contracture group }\end{array}$ & p \\
\hline Diameter of artery $(\mu \mathrm{m})$ & $\begin{array}{l}183,30 \\
(177,54 \div 185,57)\end{array}$ & $\begin{array}{l}212,21 \\
(186,49 \div 249,98)\end{array}$ & 0,0004 \\
\hline Lumen diameter $(\mu \mathrm{m})$ & $96,61(94,44 \div 99,39)$ & $78,20(60,87 \div 108,24)$ & 0,0083 \\
\hline Wall thickness $(\mu \mathrm{m})$ & $42,09(38,72 \div 43,20)$ & $67,24(57,90 \div 75,01)$ & $1,01 \mathrm{E}-09$ \\
\hline Thickness of intima $(\mu \mathrm{m})$ & $2,85(2,55 \div 3,71)$ & $13,19(9,00 \div 9,06)$ & $2,73 \mathrm{E}-11$ \\
\hline Thickness of media $(\mu \mathrm{m})$ & $24,45(24,17 \div 24,73)$ & $33,47(27,36 \div 38,04)$ & $3,88 \mathrm{E}-06$ \\
\hline $\begin{array}{l}\text { Intima/ media thickness } \\
\text { ratio }\end{array}$ & $0,12(0,09 \div 0,15)$ & $0,39(0,26 \div 0,61)$ & $4,52 \mathrm{E}-10$ \\
\hline
\end{tabular}

Table 4. Morphometric characteristics of arteries of large (L) caliber in control subjects and Dupuytren's contracture group (Me (Q1; Q3))

\begin{tabular}{|l|l|l|l|}
\hline $\begin{array}{l}\text { Group/ } \\
\text { parameters }\end{array}$ & Control & $\begin{array}{l}\text { Dupuytren's } \\
\text { contracture group }\end{array}$ & p \\
\hline Diameter of artery $(\mu \mathrm{m})$ & $\begin{array}{l}412,80 \\
(351,43 \div 506,31)\end{array}$ & $\begin{array}{l}333,33(309,06 \div- \\
375,31)\end{array}$ & 0,0022 \\
\hline Lumen diameter $(\mu \mathrm{m})$ & $\begin{array}{l}243,15 \\
(223,07 \div 326,52)\end{array}$ & $\begin{array}{l}148,74 \\
(102,45 \div 177,86)\end{array}$ & $3,49 \mathrm{E}-06$ \\
\hline Wall thickness $(\mu \mathrm{m})$ & $89,03(65,97 \div 88,88)$ & $106,12(87,05 \div 128,92)$ & 0,0556 \\
\hline Thickness of intima $(\mu \mathrm{m})$ & $8,41(7,80 \div 0,82)$ & $22,86(17,69 \div 33,42)$ & 0,0013 \\
\hline Thickness of media $(\mu \mathrm{m})$ & $58,45(44,01 \div 60,28)$ & $49,60(40,77 \div 64,03)$ & $>0,05$ \\
\hline $\begin{array}{l}\text { Intima/ media thickness } \\
\text { ratio }\end{array}$ & $0,18(0,12 \div 0,24)$ & $0,53(0,25 \div 0,69)$ & 0,0008 \\
\hline
\end{tabular}

palmar digital arteries for ring and small fingers and superficial palmar arc). In superficial palmar arc Vm decrease at 25-35\%, Vm/Vs less than $50 \%$, negative Vad values, Qas increase at $130-150 \%$, Qam decrease at $75-85 \%$ and PI increase at $40-55 \%$ regarding the values of the norm were recorded.

\section{Discussion}

Superficial palmar arc is the main palmar artery [12] which gives rise to common digital arteries and provides blood supply for extrinsic muscles tendons, lumbrical muscles and palmar fasciocutaneous complex. Through palmar aponeurosis, about 30 vascular bundles pass to the skin of the palm [13]. In the samples of operatively excised palmar fascia we revealed neurovascular bundles which contained the arteries with external diameter from 150 to $600 \mathrm{mkm}$ corresponding to those perforating arteries described by D. Bajanbeleg [14] and many arteries with smaller external diameters. Depending on the number of layers of smooth muscle cells in media, we conditionally divided them into arteries of large, medium and small calibers; by the diameter of the lumen, they all refer to small arteries and arterioles [15]. According our microscopic observation the narrowing of arterial lumen in Dupuytren's contracture begins in the smallest arteries of palmar fascia, large caliber arteries undergone severe remodeling in 3-4 stages of disease. Morphometric analysis allowed revealing that small caliber arteries did not changed their external diameter, but luminal diameter decreased predominantly due to intimal thickening. In medium caliber arteries the luminal diameter also decreased due to intimal thickening, but they underwent more expressed changes: their outer diameter and media thickness increased. In the large caliber arteries the outer and lumen diameter decreased, but intima thickness also increased due to severe neo-intima formation.

To the best of our knowledge, a morphometric characteristic of arterial structural remodeling in palmar fascia during Dupuytren's contracture was presented for the first time. And this is the first study where hemodynamic signs of vasoconstriction were recorded using PUDVM in Dupuytren's contracture patients. Earlier such changes of regional hemodynamics as retrograde blood flow and negative values of diastolic velocity were observed in healthy men and women only in the conditions of cold probe [16]. Decrease of all calculated PUDVM values in arteries of digital phalanxes - evidence of vasoconstriction was noted in patients with consequences of cold trauma [17]. contracture patients it is necessary to compare the obtained data with the in the process of aging. The most significant restructuring is a decrease in the number of microvessels [18]. In our research of Dupuytren's contracture the shares of microvessels in the tissue sections areas was much smaller in patients older than 55 years than in younger subgroup. Along with the change in the number of microvessels in the process of aging, there is a change in the size of large and small arteries which is called remodeling [19] and may include or not include the thickening of the intima due to the formation of a new inner (neo-intimal) layer.

Normal aging is characterized by increase of the arteries lumen and outer diameter with medial thickening; the peripheral vascular resistance does not change and vasodilator reactions do not altered [15]. In our research in Dupuytren's contracture patients the decrease of arteries luminal diameters and increase of intima/media thickness ratio were revealed - the evidence of constrictive remodeling corresponding to accelerated ageing which is well known characteristic of essential hypertension and diabetes of second type [15]. Recently
Since elderly and older people predominate among Dupuytren's information available in the literature about vascular bed remodeling 


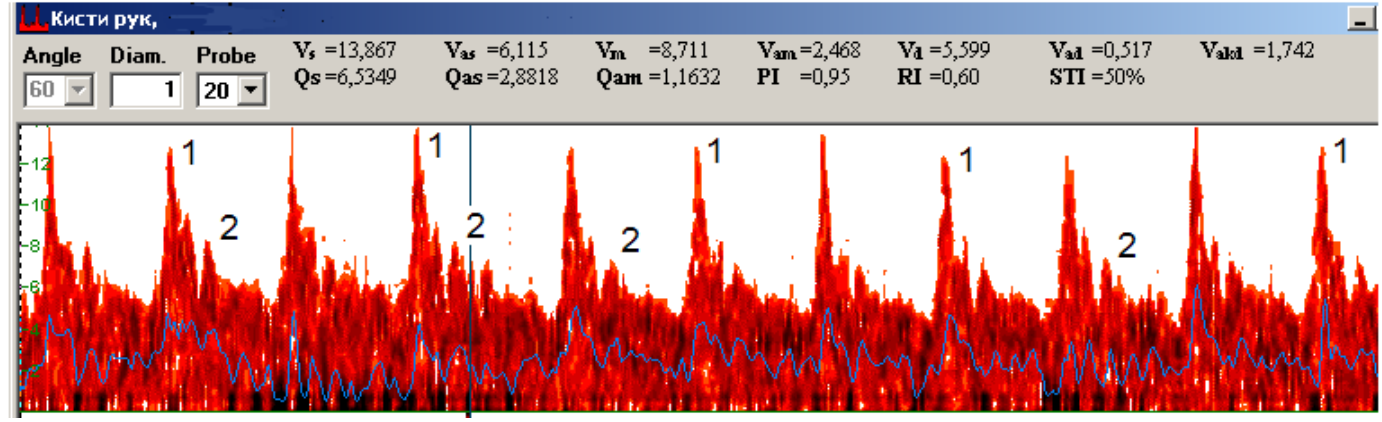

Figure 4. Pulsed ultrasound Doppler velocimetry in proper palmar digital artery of healthy subject: 1 - the systolic peak, 2 - the second anterograde peak.

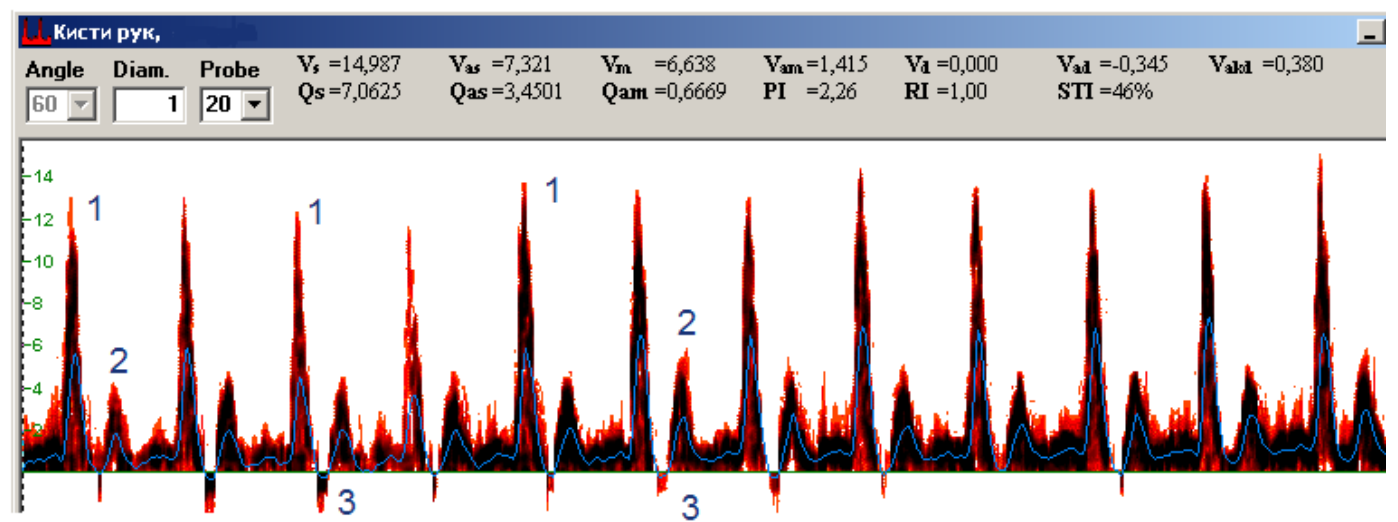

Figure 5. Pulsed ultrasound Doppler velocimetry in proper palmar digital artery of Dupuytren's contracture patiient: 1 - the systolic peak, 2 - the second anterograde peak. 3 - retrograde flow.

Table 5. Characteristics of hemodynamics in hand arteries of healthy subjects $(\mathrm{N})$ and Dupuytren's contracture (DC) patients - (Me (Q1; Q3))

\begin{tabular}{|c|c|c|c|c|c|c|c|}
\hline Parameters & $\begin{array}{l}N \\
\text { (all fingers) } \\
n=15\end{array}$ & $\begin{array}{l}\text { DC } \\
\text { thumb } \\
n=10\end{array}$ & $\begin{array}{l}\text { DC } \\
\text { index } \\
n=10\end{array}$ & $\begin{array}{l}D C \\
\text { middle finger } \\
n=10\end{array}$ & $\begin{array}{l}D C \\
\text { ring } \\
\text { finger } \\
n=10\end{array}$ & $\begin{array}{l}D C \\
\text { small } \\
\text { finger } \\
n=10\end{array}$ & $\begin{array}{l}\text { DC superficial } \\
\text { palmar arc } \\
n=10\end{array}$ \\
\hline $\begin{array}{l}\text { Vs - systolic blood } \\
\text { flow velocity }\end{array}$ & $\begin{array}{l}16,98 \\
(13,5 \div \\
20,2)\end{array}$ & $\begin{array}{l}17,92 \\
(12,23 \div \\
18,26)\end{array}$ & $\begin{array}{l}13,61 \\
(11,88 \div \\
15,76)\end{array}$ & $\begin{array}{l}14,55 \\
(9,38 \div \\
14,98)\end{array}$ & $\begin{array}{l}14,0 \\
(11,28 \div \\
15,3)\end{array}$ & $\begin{array}{l}11,45^{*} \\
(9,82 \div \\
13,18) \\
p=0,0029\end{array}$ & $\begin{array}{l}12,48 \\
(11,0 \div \\
17,17)\end{array}$ \\
\hline $\begin{array}{l}\text { Vm- } \\
\text { mean linear velocity }\end{array}$ & $\begin{array}{l}9,37 \\
(7,8 \div 10,2)\end{array}$ & $\begin{array}{l}7,6 \\
(6,4 \div \\
8,0)\end{array}$ & $\begin{array}{l}7,36 \\
(5,63 \div 7,88)\end{array}$ & $\begin{array}{l}6,79 * \\
(6,01 \div 7,16) \\
p=0,0050\end{array}$ & $\begin{array}{l}6,37 * \\
(4,62 \div 6,64) \\
p=0,0043\end{array}$ & $\begin{array}{l}6,51 * \\
(4,93 \div 6,62) \\
p=0,0026\end{array}$ & $\begin{array}{l}7,22 * \\
(5,44 \div 7,76) \\
p=0,0022\end{array}$ \\
\hline $\begin{array}{l}(\mathrm{Vm} / \mathrm{Vs}) \\
* 100 \%\end{array}$ & $\begin{array}{l}61,4 \\
(57,6 \div 62,5)\end{array}$ & $\begin{array}{l}49,4^{*} \\
(38,7 \div 51,5) \\
p=0,0281\end{array}$ & $\begin{array}{l}47,4 * \\
(44,6 \div 49,3) \\
p=0,0080\end{array}$ & $\begin{array}{l}42,4 * \\
(40,0 \div 52,4) \\
p=0,0092\end{array}$ & $\begin{array}{l}48,5^{*} \\
(31,7 \div 48,5) \\
p=0,0026\end{array}$ & $\begin{array}{l}48,9 * \\
(43,2 \div 51,9) \\
p=0,0127\end{array}$ & $\begin{array}{l}43,0 * \\
(33,7 \div 48,2) \\
p=0,0069\end{array}$ \\
\hline $\begin{array}{l}\text { VAd- e maximum } \\
\text { diastolic velocity }\end{array}$ & $\begin{array}{l}0,517 \\
(0,130 \div \\
0,951)\end{array}$ & $\begin{array}{l}0,172 \\
(-0,517 \div \\
0,345)\end{array}$ & $\begin{array}{l}0,603 \\
(-0,258 \div \\
0,689)\end{array}$ & $\begin{array}{l}0,172 \\
(0,00 \div \\
0,258)\end{array}$ & $\begin{array}{l}-0,345^{*} \\
(-0,517 \div \\
-0,086) \\
p=0,0011\end{array}$ & $\begin{array}{l}-0,172 * \\
(-0,345 \div 0,00) \\
p=0,0045\end{array}$ & $\begin{array}{l}-0,345^{*} \\
(-0,345 \div \\
-0,172) \\
p=0,0017\end{array}$ \\
\hline $\begin{array}{l}\text { Qas- } \\
\text { volume systolic } \\
\text { velicity }\end{array}$ & $\begin{array}{l}2,43 \\
(1,46 \div \\
3,08)\end{array}$ & $\begin{array}{l}7,06^{*} \\
(7,52 \div \\
7,63) \\
\mathrm{p}=0,0003\end{array}$ & $\begin{array}{l}6,16^{*} \\
(4,83 \div \\
4,61) \\
p=0,0007\end{array}$ & $\begin{array}{l}6,85^{*} \\
(4,38 \div \\
7,06) \\
p=0,00005\end{array}$ & $\begin{array}{l}5,68^{*} \\
(4,86 \div \\
6,61) \\
p=0,00015\end{array}$ & $\begin{array}{l}5,23 * \\
(4,18 \div \\
6,21) \\
p=0,0095\end{array}$ & $\begin{array}{l}5,72 * \\
(4,46 \div \\
5,88) \\
\mathrm{p}=0,0005\end{array}$ \\
\hline $\begin{array}{l}\text { Qam- } \\
\text { mean } \\
\text { volume } \\
\text { velocity }\end{array}$ & $\begin{array}{l}1,05 \\
(0,62 \div \\
1,16)\end{array}$ & $\begin{array}{l}0,58 \\
(0,27 \div \\
0,73)\end{array}$ & $\begin{array}{l}0,72 \\
(0,18 \div \\
0,76)\end{array}$ & $\begin{array}{l}0,71 \\
(0,33 \div \\
0,72)\end{array}$ & $\begin{array}{l}0,48^{*} \\
(0,30 \div \\
0,66) \\
p=0,0195\end{array}$ & $\begin{array}{l}0,41 * \\
(0,14 \div \\
0,47) \\
p=0,0195\end{array}$ & $\begin{array}{l}0,26 * \\
(0,04 \div \\
0,61) \\
p=0,0036\end{array}$ \\
\hline PI-pulsatility index & $\begin{array}{l}1,2 \\
(0,97 \div \\
1,37)\end{array}$ & $\begin{array}{l}1,69^{*} \\
(1,55 \div \\
1,75) \\
\mathrm{p}=0,0116\end{array}$ & $\begin{array}{l}1,63 * \\
(1,52 \div \\
1,64) \\
p=0,0276\end{array}$ & $\begin{array}{l}1,50 * \\
(1,34 \div \\
1,60) \\
\mathrm{p}=0,0456\end{array}$ & $\begin{array}{l}1,68^{*} \\
(1,36 \div \\
1,75) \\
p=0,0084\end{array}$ & $\begin{array}{l}1,48^{*} \\
(1,40 \div \\
1,65) \\
\mathrm{p}=0,0084\end{array}$ & $\begin{array}{l}1,83 * \\
(1,54 \div \\
1,93) \\
p=0,0064\end{array}$ \\
\hline RI- resistance index & $\begin{array}{l}0,76 \\
(0,63 \div \\
0,91)\end{array}$ & $\begin{array}{l}0,75 \\
(0,62 \div \\
0,84)\end{array}$ & $\begin{array}{l}0,78 \\
(0,75 \div \\
0,80)\end{array}$ & $\begin{array}{l}0,76 \\
(0,71 \div \\
0,76)\end{array}$ & $\begin{array}{l}0,83 \\
(0,80 \div \\
0,86)\end{array}$ & $\begin{array}{l}0,82 \\
(0,77 \div \\
0,84)\end{array}$ & $\begin{array}{l}0,84 \\
(0,79 \div \\
0,86)\end{array}$ \\
\hline
\end{tabular}


such changes were solved for normotensive patients with systemic lupus erythematosus [20].

With accelerated aging, endothelium-dependent dilatation of the vessels is lost as a result of oxidative stress and chronic proinflammatory status; the last tend to endothelial apoptosis - senescent endotheliocytes enlarged in size and easy to exfoliate [21]. Proliferative activity of smooth muscle cells increase in ageing, many of them migrate from media into intima and substantiate dead endotheliocytes - this is a key event in neo-intima formation; breakdown of elastic membranes in muscular arteries due to increased level of matrix proteases expression facilitates migration of smooth muscle cells [18, 21]. Vascular adventitial layer contains resident cells of immune system and progenitor cells which regulate vascular remodeling [22].

Mechanism of constrictive vascular remodeling is not fully understood but reduction in lumen and outer diameter of the artery occurs as a result of two processes: neo-intimal layer formation in response to endothelial damage and shrinkage of artery wall as a result of cellular migration into the space of intima and matrix restructurization [23]. Constrictive remodeling is mediated by increased proliferation of adventitial fibroblasts and myofibroblasts, by increased rigidity of adventitia due to fibrosis; it was suggested that the process is initiated by inflammatory cells which accumulate in periadventitial spaces [24]. Clusters of T-lymphocytes round vessels with thickened walls and narrowed lumens were discovered in palmar fascia of Dupuytren's contracture patients [4]. In our research higher per cents of vessels with peri-adventitial clusters of inflammatory cells were noted in patients younger than 55 years.

Myofibroblasts combining the properties of fibroblasts and contractile smooth muscle cells are responsible not only for constrictive vascular remodeling during accelerated ageing and vascular diseases, but also for the development of fibromatosis in Dupuytren's contracture [25].

Previously it was considered that latent vasospasm in digital arteries of Dupuytren's contracture is independent constitutional phenomenon, not connected with proliferative processes in palmar fascia [5]. G.A. Murell [26] put forward another hypothesis: vessels narrowing, hypoxia and activation of xanthine oxidases lead to fibroblasts transformations and development of fibromatosis [27].

As conclusion hemodynamic signs of vasoconstriction at the level of superficial palmar were in accordance with structural constrictive remodeling of palmar fascia arteries, the severity of the last depended on stage of Dupuytren's contracture and arterial caliber. Further explorations of functional characteristics and structural changes of hand vasculature in Dupuytren's contracture in dependence of age, gender and comorbid conditions are necessary for clarification of individually oriented protocols of additive therapy.

\section{Acknowledgements}

We are grateful to all those who participated in this study

\section{Competing interests}

The authors declare that they have no competing interests.

\section{Availability of data and materials}

No additional data are available.

\section{Ethics approval and consent to participate}

The study protocol was performed in accordance with ethics principles. A subjects' written consent was obtained. Analysis was conducted on anonymized data.

\section{Funding}

Research was supported with program of the RF Ministry of Health within government-mandated program for FSBI Russian Ilizarov Scientific Center "Restorative Traumatology and Orthopaedics" (RISC "RTO") for Scientific Research in 2018-2020 Yr. / Yrs.

\section{Consent for publication}

Not applicable.

\section{Authors' contributions}

ShchN, VT, ST, DT, ShchM, ShN and KV substantially contributed to the concept and design of the study, collection of material, statistical analysis, analysis and interpretation of data; all authors drafted the article and made critical revisions related to the intellectual content of the manuscript and approved the final version of the article to be published.

\section{References}

1. Reilly RM, Stern PJ, Goldfarb CA (2005) A retrospective review of the management of Dupuytren's nodules. J Hand Surg Am 30: 1014-1018. [Crossref]

2. Larsen S, Krogsgaard DG, Aagaard Larsen L, Iachina M, Skytthe A, et al. (2015) Genetic and environmental influences in Dupuytren's disease: a study of 30,330 Danish twin pairs. J Hand Surg Eur 40: 171-176. [Crossref]

3. Thurston AJ (2003) Dupuytren's disease. J Bone Joint Surg Br 85: 469-477. [Crossref]

4. Mayerl C, Del Frari B, Parson W, Boeck G, Piza-Katzer H, et al. (2016) Characterisation of the inflammatory response in Dupuytren's disease. J Plast Surg Hand Surg 50: 171179. [Crossref]

5. Bauer M, Hussl H, Höpfel-Kreiner I, Polaczek R (1980) Blood flow in the finger in Dupuytren's contracture. Plethysmographic, histological and neurological findings. Chirurgia plastica 5: 243-248

6. Stefanczyk L, Wozniakowski B, Pietrzak P, Majos A, Grzelak P, et al. (2007) Comparison of thermography and Doppler sonography in the evaluation of the cold immersion test in women with excessive vasospastic reaction. Med Sci Monit 13: 121128. [Crossref]

7. Morecraft R, Blair WF, Brown TD, Gable RH (1994) Acute effects of smoking on digital artery blood flow in humans. J Hand Surg Am 19: 1-7. [Crossref]

8. Tubiana R (1999) Dupuytren's disease of the radial side of the hand. Hand Clin 15 149-159. [Crossref]

9. Rayan GM, Moore J (2005) Non-Dupuytren's disease of the palmar fascia. $J$ Hand Surg $\mathrm{Br}$ 30: 551-556. [Crossref]

10. Fazan VP, Borges CT, Da Silva JH, Caetano AG, Filho OAR, et al. (2004) Superficial palmar arch: an arterial diameter study. J Anat 204: 307-311. [Crossref]

11. Blair WF, Brown TD, Greene ER (1988) Pulsed ultrasound Doppler velocimetry in the assessment of microvascular hemodynamics. J Orthop Res 6: 300-309. [Crossref]

12. Gajisin S, Zbrodowski A (1993) Local vascular contribution of the superficial palmar arch. Acta Anat (Basel) 147: 248-251. [Crossref]

13. Elsner T, Schramm U, Schrader M (2001) Analysis of the vascular anatomy of the palm and its clinical relevance in Morbus Dupuytren. Ann Anat 183: 379-382. [Crossref]

14. Baianbeleg D (1972) [Blood vessels of the human palmar aponeurosis]. Arkh Anat Gistol Embriol 62: 82-88. [Crossref]

15. Early Vascular Aging (EVA). New Directions in Cardiovascular Protection Edited by: Peter Nilsson, Michael Olsen, Stephane Laurent. 2015; Academic Press, 376 ?.

16. Dolganova TI, Shikhaleva NG (2008) Normal USDG measurements of the hand digital arteries. Regional hemodynamics and microcirculation 4: 24-28.

17. Dolganova TI, Shabalin DA, Shikhaleva NG (2011) Doppler sonography of digital arteries by lengthening of finger phalanges with minifixators. Traumatology and Orthopedics of Russia 2: 107-113.

18. Xu X, Wang B, Ren C, Hu J, Greenberg DA, et al. (2017) Age-related Impairment of Vascular Structure and Functions. Aging Dis 8: 590-610. [Crossref] 
19. Schwartz RS, Topol EJ, Serruys PW, Sangiorgi G, Holmes DR Jr (1998) Artery size, neointima, and remodeling: time for some standards. J Am Coll Cardiol 32: 2087-2094. [Crossref]

20. Morreale M, Mulè G, Ferrante A, D'ignoto F, Cottone S, et al. (2016) Early Vascular Aging in Normotensive Patients With Systemic Lupus Erythematosus: Comparison With Young Patients Having Hypertension. Angiology 67: 676-682. [Crossref]

21. Wang M, Jiang L, Monticone RE, Lakatta EG (2014) Proinflammation: the key to arterial aging. Trends Endocrinol Metab 25: 72-79. [Crossref]

22. Majesky MW, Dong XR, Hoglund V, Daum G, Mahoney WM Jr (2012) The adventitia: a progenitor cell niche for the vessel wall. Cells Tissues Organs 195: 73-81. [Crossref]
23. Geary RL, Nikkari ST, Wagner WD, Williams JK, Adams MR, et al. (1998) Wound healing: a paradigm for lumen narrowing after arterial reconstruction. J Vasc Surg 27: 96-106. [Crossref]

24. Coen M, Gabbiani G, Bochaton-Piallat ML (2011) Myofibroblast-mediated adventitial remodeling: an underestimated player in arterial pathology. Arterioscler Thromb Vasc Biol 31: 2391-2396. [Crossref]

25. Tomasek JJ, Vaughan MB, Haaksma CJ (1999) Cellular structure and biology of Dupuytren's disease. Hand Clin 15: 21-34. [Crossref]

26. Murrell GA (1991) The role of the fibroblast in Dupuytren's contracture. Hand Clin 7: 669-680. [Crossref]

27. Murrell GA, Francis MJ, Howlett CR (1989) Dupuytren's contracture. Fine structure in relation to aetiology. J Bone Joint Surg Br 71:367-373. [Crossref]

Copyright: $@ 2018$ Shchudlo N. This is an open-access article distributed under the terms of the Creative Commons Attribution License, which permits unrestricted use, distribution, and reproduction in any medium, provided the original author and source are credited. 